Новий підхід до визначення антирадикальної ємності поліфенолів в реакції з катіон-радикалом 2,2'-азинобіс(3-етилбензтіазолін-6-сульфонової кислоти) / В. В. Одарюк, Г. К. Сігаєва, Л. В. Каніболочька, О. О. Зосенко, О. М. Шендрик // Вісник Донецького начіонального університету імені Василя Стуса. Серія хімічні науки. 2017. № 1. C. 25-31

УДК 547.(565+789.1)

\title{
НОВИЙ ПІДХІД ДО ВИЗНАЧЕННЯ АНТИРАДИКАЛЬНОЇ ЄМНОСТІ ПОЛІФЕНОЛІВ В РЕАКЦІї 3 КАТІОН-РАДИКАЛОМ 2,2'-АЗИНО- БІС(3-ЕТИЛБЕНЗТІАЗОЛІН-6-СУЛЬФОНОВОЇ КИСЛОТИ)
}

\author{
В. В. Одарюк ${ }^{*}$, Г. К. Сігаєва, Л. В. Каніболоцька, О. О. Зосенко, О. М. Шендрик \\ Донецький національний університет імені Василя Стуса, м. Вінниця, Україна
}

\begin{abstract}
Запропонований підхід до визначення стехіометричного коефіцієнту інгібування фенольними антиоксидантами в реакції з катіон-радикалом 2,2-азинобіс(3-етилбензтіазолін-6-сульфонової кислоти) $\left(\mathrm{ABTS}^{\bullet+}\right)$, що дозволяє виключити вплив продуктів перетворення антиоксиданту на показник антирадикальної здатності. Висока антирадикальна здатність похідних дигідроксифенілтіазолу (ДФТ) в реакції з $\mathrm{ABTS}^{++}$обумовлена впливом продуктів перетворення ДФТ. Обговорюється механізм процесу.

Ключові слова: антирадикальна здатність, антиоксиданти, дигідроксибензоли, дигідроксифенілтіазоли, водне середовище, АBTS.
\end{abstract}

\section{Вступ}

Серед методів визначення антирадикальних властивостей антиоксидантів (АО) у модельних системах значне місце посідають реакції зі стабільними радикалами - 1,1-дифеніл-2-пікрилгідразилом (DPPH) та катіон-радикалом 2,2'-азинобіс(3-етилбензтіазолін-6сульфонової кислоти) $\left(\mathrm{ABTS}^{\bullet+}\right)$, що пояснюється відносно низькою вартістю реагентів та простотою процедур [1]. Перевага використання радикала $\mathrm{ABTS}^{\circ+}$ обумовлена його амфіфільністю і стабільністю в широкому діапазоні рН (від 2.0 до 10.5 [2]). В той же час досі немає єдиної думки щодо сполуки-еталону (антиоксидантного стандарту) та часу експозиції реакційної суміші перед вимірами. Час витримування $є$ критичним параметром для одержання достовірних та придатних для порівняння результатів. Це пов'язано з тим, що кінетичні профілі реакції з $\mathrm{ABTS}^{\bullet+}$ для різних індивідуальних сполук помітно відрізняються [3]. Для багатьох субстратів антирадикальна здатність збільшується із збільшенням часу реакції [4].

В даній роботі обгрунтовано новий підхід до визначення антирадикальной ємності індивідуальних сполук: двохатомних фенолів та

\footnotetext{
* E-mail: v.odariuk@donnu.edu.ua

( ) В. В. Одарюк, Г. К. Сігаєва, Л. В. Каніболоцька, О. О. Зосенко, О. М. Шендрик, 2017
} дроксифеніл)тіазолу, що проявляють як антиокисні, так і антибактеріальні властивості $[5,6]$.

\section{Експериментльна частина}

Похідні дигідроксифенілтіазолу синтезовані за методом Ганча [7] реакцією фенацилхлоридів з відповідними тіоамідами, структури досліджених сполук наведено в таблиці.

Діамонієва сіль 2,2'-азинобис(3-етилбензтіазолін-6-сульфонової кислоти) (ABTS), 6-гідрокси-2,5,7,8-тетраметилхроман-2-кар-

бонова кислота - Тролокс, солі для приготування буферного розчину - $\mathrm{Na}_{2} \mathrm{PO}_{4} \cdot 2 \mathrm{H}_{2} \mathrm{O}$, $\mathrm{NaHPO}_{4} \cdot \mathrm{H}_{2} \mathrm{O}$ (Sigma-Aldrich) застосовувалися без додаткової очистки. Пірокатехін піддавали сублімації під зниженим тиском. Всі робочі розчини готували на бідистильованій воді безпосередньо перед серією дослідів.

Визначення антирадикальної здатності індивідуальних сполук в реакиії з попередньо генерованим ABTS ${ }^{\circ}$. Вихідний розчин катіонрадикала $\mathrm{ABTS}^{\circ+}$ готували за методикою [8]. Для визначення антирадикальної здатності змішували розчин $\mathrm{ABTS}^{\circ+}$ i аліквоту досліджуваної сполуки і реєстрували зниження абсорбції при 734 нм. Стехіометричний коефіцієнт $f_{A B T S} \cdot+$ визначали з графіку залежності 
кількості $\mathrm{ABTS}^{\bullet+}$, що прореагувало, від початкової концентрації доданого антиоксиданту.

Визначення антирадикальної здатності способом радикал-відновлювального інгібування. Запропонований у роботі спосіб визначення антирадикальної ємності грунтується на відновленні in situ катіон-радикалу ABTS ${ }^{*+}$ фенольним антиоксидантом в реакційній системі. Стехіометричний коефіцієнт інгібування ( $\left.f_{A B T S+}^{r e d}\right)$ визначали із тривалості періоду індукції $(\tau)$ в реакції окислення ABTS персульфатом калію в присутності різних концентрацій антиоксиданту:

$$
f_{A B T S+}^{r e d}=\frac{V_{A B T s^{++}} \cdot \tau}{C_{0}(A O)}=\frac{V_{A B T s^{++}}}{V_{-A B T S^{++}}},
$$

де $V_{A B T S \cdot+}=5.0 \pm 0.5\left(\mathrm{M} \cdot \mathrm{c}^{-1}\right)-$ швидкість накопичення катіон-радикала $\mathrm{ABTS}^{++}$у реакції ABTS $3 \mathrm{~K}_{2} \mathrm{~S}_{2} \mathrm{O}_{8}$ за відсутності $\mathrm{AO}$ (визначали в окремому досліді); $V_{-A B T S •+}$ - швидкість витрачання катіон-радикала $\mathrm{ABTS}^{\circ+}$ у реакції 3 антиоксидантом; $C_{0}(A O)$ - початкова концентрація антиоксиданту.

Для цього в кюветі змішували розчин ABTS $\left(C_{0}=0,4 \mathrm{MM}\right)$, розчин антиоксиданту в діапазоні концентрацій $\left(1 \cdot 10^{-7}-2 \cdot 10^{-5} \mathrm{M}\right)$ і розчин персульфату калію $\left(C_{0}=0,4 \mathrm{MM}\right)$. Накопичення катіон-радикала $\mathrm{ABTS}^{\cdot+}$ реєстрували при $\lambda=417$ нм. Виміри проводили на швидкісному UV-VIS спектрофотометрі Specord S300 (Німеччина).

\section{Результати та їх обговорення}

Для цілого ряду фенольних сполук в реакції 3 катіон-радикалом ABTS $^{\cdot+}$ спостерігається двоетапна кінетика $[9,10]$. На відміну від стандартного антиоксиданту Тролоксу, для двохатомних фенолів і ДФТ в реакції з попередньо генерованим $\mathrm{ABTS}^{\cdot+}$ на кривій витрачання катіон-радикалу спостерігається помітне зниження концентрації $\mathrm{ABTS}^{\bullet+}$ на другій ділянці кінетичної кривої (рис. 1). Чим швидше витрачається катіон-радикал на цій «повільній» ділянці, тим більшою буде розбіжність у антирадикальній ємності, що кількісно оцінюється величиною стехіометричного

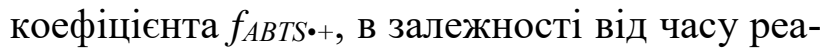

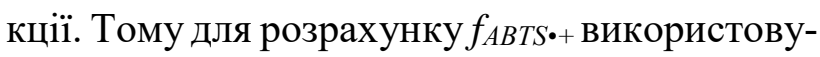
вали кількість катіон-радикалу, що витратився на першій «швидкій» ділянці кінетичної кривої. Отримані результати наведені в таблиці.

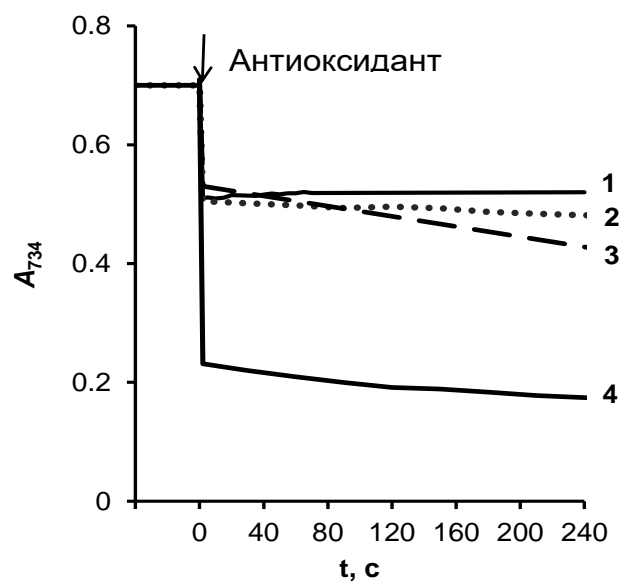

Рис. 1. Кінетичні криві витрачання $\mathrm{ABTS}^{\bullet+}$ в реакції з антиоксидантами, фосфатна буферна система, $\mathrm{pH} 7.4, C_{0}(\mathrm{ABTS})_{0}=0,047 \mathrm{MM}$.

$1-$ Тролокс, $C_{0}$ (Трол) $=0,0057$ мM; 2 - Пірокатехін, $C_{0}(\Pi К)=0,005 \mathrm{мM} ; \quad 3-$ ДФТ VI, $\quad C_{0}($ ДФТ VI $)=$ 0,0057 мМ; 4 - Резорцин, $C_{0}$ (РЦ) = 0,005 мМ

Якщо для сполук I-VIII, XII-XIV значення $f_{A B T S} \cdot+$ добре узгоджуються $з$ наявністю в молекулах двох гідроксильних груп, здатних виступати донорами електронів для відновлення катіон-радикалу (схема 1), то для резорцину (XV) та $\mathrm{N}$-ариламінозаміщених похідних дигідроксифенілтіазолу (VIII-XI) спостерігаються високі значення $f_{A B T S \cdot+}$ (таблиця).

Для з'ясування причин високої антирадикальної здатності $\mathrm{N}$-ариламінопохідних тіазолу було використано інший спосіб визначення стехіометричного коефіцієнту $f_{A B T S} \cdot+$, заснований на інгібуванні антиоксидантом окислення ABTS персульфатом калію. Подібний підхід описаний в роботі [11], але антирадикальні властивості індивідуальних сполук автори оцінювали в масових концентраціях відносно Тролоксу, що ускладнює порівняння результатів внаслідок розбіжностей в кінетиці цих реакцій. 
<smiles>[R]C1=CC(=O)C(=O)C=CC1=O</smiles>

Схема 1. Механізм антирадикальної дії двохатомних фенолів і їх похідних в реакції з попередньо генерованим катіон-радикалом $\mathrm{ABTS}^{++}$

За відсутності інгібітора, молекула ABTS окислюється персульфатом калію за реакцією (2), і фіксується зростання поглинання в характерних для $\mathrm{ABTS}^{*+}$ областях спектра.

$$
\text { ABTS } \stackrel{\mathrm{S}_{2} \mathrm{O}_{8}^{2-}}{\longrightarrow} \mathrm{ABTS}^{\cdot+} \text {. }
$$

У присутності антиоксиданту відбувається миттєве відновлення катіон-радикала 3 утворенням вихідної молекули ABTS. На кінетичних кривих накопичення $\mathrm{ABTS}^{\circ}$, в цьому випадку, з'являються періоди індукції (рис. 2), тривалість яких пропорційна початковій концентрації доданого антиоксиданту (рис. 3).

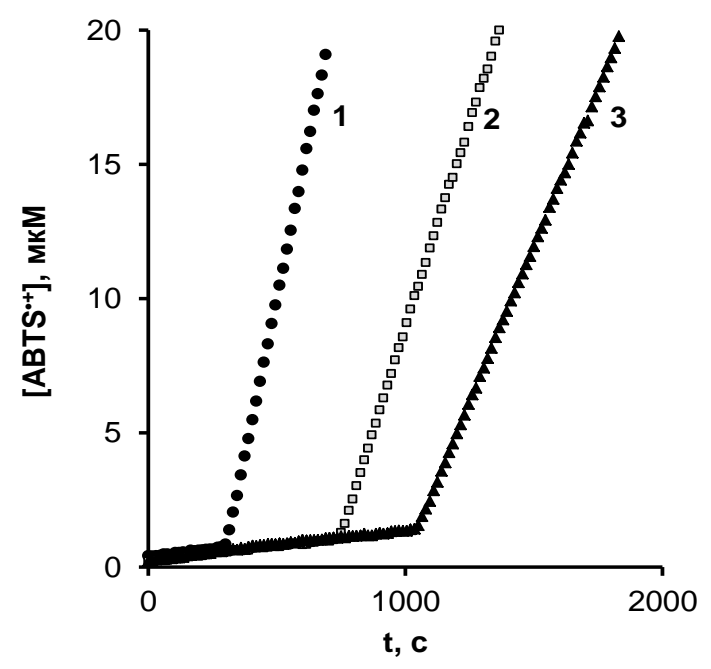

Рис. 2. Накопичення $\mathrm{ABTS}^{\bullet+}$ в реакції $3 \mathrm{~K}_{2} \mathrm{~S}_{2} \mathrm{O}_{8}$ в присутності пірокатехіну. $C_{0}(\mathrm{ABTS})=C_{0}\left(\mathrm{~K}_{2} \mathrm{~S}_{2} \mathrm{O}_{8}\right)_{0}=$ 0,4 мМ, фосфатний буфер, pH 7.4, T = 298 K. 1 $C_{0}(\Pi К)=0,01$ мМ; $2-C_{0}(\Pi К)=0,02$ мM; $3-C_{0}(\Pi К)$ $=0,03 \mathrm{MM}$
Після повного витрачення антиоксиданту накопичення $\mathrm{ABTS}^{\circ+}$ відновлюється, але відбувається зі швидкістю нижчою, ніж за умов неінгібованого окислення. Швидкість утворення $\mathrm{ABTS}^{\cdot+}$ по закінченню періоду індукції змінюється антибатно до початкової концентрації інгібітора в системі (рис. 4).

Імовірною причиною зменшення швидкості утворення $\mathrm{ABTS}^{*+}$ за реакцією (2) по завершенню лаг-періода у присутності фенольного антиоксиданту $є$ незворотне витрачання персульфату калію протягом усього часу гальмування процесу.

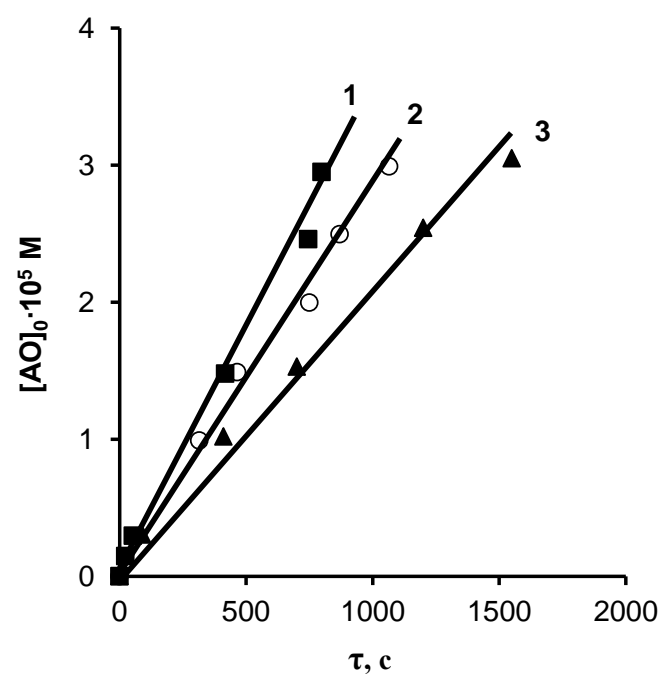

Рис. 3. Залежність між початковою концентрацією антиоксиданту i періодом індукції накопичення $\mathrm{ABTS}^{\bullet+}$. $C_{0}(\mathrm{ABTS})=C_{0}\left(\mathrm{~K}_{2} \mathrm{~S}_{2} \mathrm{O}_{8}\right)=0,4 \mathrm{MM}$, фосфатний буфер, pH 7.4, T = 298 К. 1 - ДФТ II; 2 - Пірокатехін; 3 - ДФТ VI 
Чим більша концентрація інгібітора, тим більше період індукції, і тим більшою буде кількість персульфату, який прореагував 3 ABTS. На підтвердження цього було досліджено залежність швидкості утворення $\mathrm{ABTS}^{\cdot+}$ від концентрації персульфату калію (при $\left.C_{0}(\mathrm{ABTS})=0,4 \mathrm{MM}\right)$. Припускали, що персульфат калію витрачається за рівнянням (2) доти, доки в реакційній системі присутній антиоксидант. Кількість персульфату калію, що залишається в системі по виході з періоду індукції, визначається співвідношенням:

$$
C\left(K_{2} S_{2} O_{8}\right)=\frac{C_{0}(A B T S)-C_{0}(A O) \cdot f_{A B T S++}^{r e d}}{2} .
$$

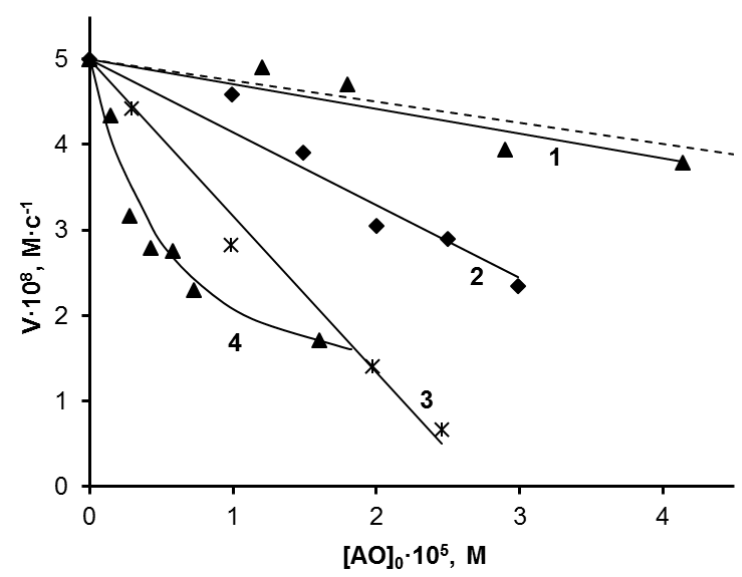

Рис. 4. Залежність швидкості накопичення $\mathrm{ABTS}^{\bullet+}$ в реакції з $\mathrm{K}_{2} \mathrm{~S}_{2} \mathrm{O}_{8}$ по закінченню періоду індукції від початкової концентрації $\mathrm{AO}$ в системі. $C_{0}(\mathrm{ABTS})=C_{0}\left(\mathrm{~K}_{2} \mathrm{~S}_{2} \mathrm{O}_{8}\right)=0,4$ мM, фосфатний буфер, pH 7.4, T=298 K. $\quad \mathbf{1}-$ Тролокс; $\quad \mathbf{2}-$ Пірокатехін (XII); 3 - ДФТ III; 4 -ДФТ X

Пунктиром позначена очікувана (розрахована) швидкість накопичення $\mathrm{ABTS}^{\cdot+}$ по закінченню періоду індукції, яка враховує витрачання персульфату калію в періоді індукції

Розрахована швидкість накопичення $\mathrm{ABTS}^{-+}$добре збігається із швидкістю накопичення $\mathrm{ABTS}^{*+}$, що спостерігається в експерименті з Тролоксом (рис. 4, пунктирна лінія). Для інших антиоксидантів експериментальні значення швидкості помітно менші за очікувану. Очевидно, це пов'язано із присутністю в реакційній системі продуктів перетворення антиоксиданту, що також проявляють антирадикальні властивості.

Між тривалістю періоду індукції і початковою концентрацією антиоксиданту (рис. 3) існує лінійна залежність, яка свідчить про те, що антиоксидант в періоді індукції витрачається $з$ постійною швидкістю. Швидкість витрачання дорівнює швидкості генерування радикалів $\mathrm{ABTS}^{\circ+}$ за реакцією з персульфатом калію $\left(V_{i}\right)$. Сталість $V_{i}$ обумовлено тим, що концентрація АО на порядок менша концентрацій $\mathrm{ABTS}$ i $\mathrm{K}_{2} \mathrm{~S}_{2} \mathrm{O}_{8}$, і протягом періоду індукції витрачається тільки антиоксидант. Відновлення катіон-радикала до молекули ABTS відбувається з тією ж швидкістю $V_{i}$.

В цілому, кінетичний цикл процесу утворення $\mathrm{ABTS}^{\circ+}$ i витрачання АО в періоді індукції буде виглядати наступним чином:

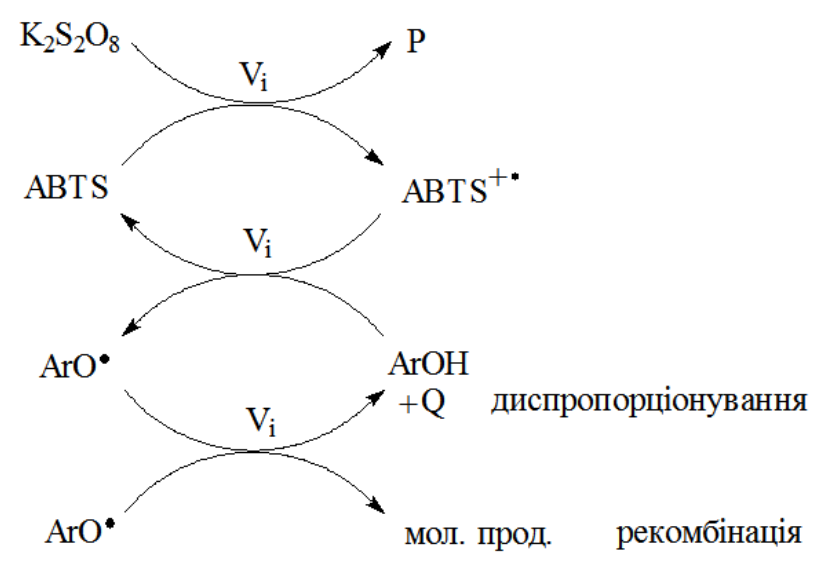

Гідроксіарильні радикали $\left(\mathrm{ArO}^{\bullet}\right)$, що утворюються, будуть перетворюватися далі в молекулярні продукти за реакціями загибелі радикалів. Ця модель дозволяє за аналогією 3 процесами інгібованого окиснення вуглеводнів використовувати співвідношення (1) для визначення стехіометричного коефіцієнта інгібування.

Розраховані за співвідношенням (1) стехіометричні коефіцієнти інгібування $\left(f_{A B T S+}^{\text {red }}\right)$ наведені в таблиці. Для сполук I-VII, XIIXIV вони збігаються в межах похибки з вели-

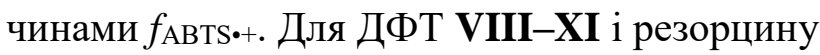
(XV) стехіометричні коефіцієнти, визначені способом радикал-відновлювального інгібування, нижчі. Вважаємо, що значення $f_{A B T S+}^{\text {red }}$ характеризують антирадикальну здатність вихідного антиоксиданту на відміну від величини $f_{\mathrm{ABTS} \cdot+}$, значення якої виражає суму антирадикальної здатності вихідного антиоксиданту і продуктів його перетворення. 
Збіг величин стехіометричних коефіцієнтів інгібування для інших сполук, знайдених за допомогою різних підходів, свідчить на користь того, що для визначення $f_{\mathrm{ABTS} \cdot+}$ методом, запропонованим R. Re [8], доцільно використовувати тільки першу «швидку» ділянку кінетичної кривої витрачання ABTS $^{\cdot+}$ (протягом перших 60 с реакції).

Таблиця. Антирадикальна здатність двохатомних фенолів та дигідроксифенілтіазолів

\begin{tabular}{|c|c|c|c|}
\hline $\begin{array}{c}\text { Шифр } \\
\text { спо- } \\
\text { луки }\end{array}$ & & $f_{\text {ABTS•+十 }}$ & $f_{A B T S+}^{r e d}$ \\
\hline I & $-\mathrm{CH}_{3}$ & $2.0 \pm 0.1$ & $1.4 \pm 0.1$ \\
\hline II & & $3.1 \pm 0.5$ & $1.5 \pm 0.2$ \\
\hline III & & $1.7 \pm 0.1$ & $1.6 \pm 0.5$ \\
\hline IV & & $2.3 \pm 0.5$ & $2.5 \pm 0.8$ \\
\hline $\mathbf{V}$ & & $2.2 \pm 0.3$ & $1.2 \pm 0.2$ \\
\hline VI & & $1.8 \pm 0.6$ & $2.4 \pm 0.2$ \\
\hline VII & & $1.4 \pm 0.2$ & $1.4 \pm 0.1$ \\
\hline VIII & & $6.0 \pm 0.4$ & $3.7 \pm 0.2$ \\
\hline IX & $-\mathrm{NH}^{-}$ & $5.7 \pm 0.2$ & $3.3 \pm 0.3$ \\
\hline $\mathbf{X}$ & & $7.5 \pm 0.3$ & $4.0 \pm 0.4$ \\
\hline XI & & $9 \pm 1$ & $2.0 \pm 0.2$ \\
\hline XII & Пірокатехін & $2.1 \pm 0.4$ & $1.8 \pm 0.3$ \\
\hline XIII & 4-Метилпірокатехін & $2.0 \pm 0.3$ & $2.3 \pm 0.8$ \\
\hline XIV & Тролокс & $2.0 \pm 0.2$ & $1.9 \pm 0.1$ \\
\hline $\mathbf{X V}$ & Резорцин & $5.0 \pm 1.5$ & $2.5 \pm 0.5$ \\
\hline
\end{tabular}

Для сполук VIII-X високі значення стехіометричного коефіцієнту інгібування (більше 2) можуть бути обумовлені наявністю додаткового реакційного центру. Ним $є$ іонізована форма сульфаніламідного фрагменту, що здатна виступати донором електрону. Високі значення стехіомеричного коефіцієнту інгібування для резорцину обумовлені утворенням аддуктів з радикалом $\mathrm{ABTS}^{\bullet+}[10,12]$.

На прикладі похідних ДФТ сполук добре ілюструється перевага способа радикал-відновлювального інгібування для дослідження антирадикальної здатності складних антиоксидантів.

\section{Висновки}

Розроблено і експериментально обгрунтовано новий підхід до визначення антирадикальної ємності індивідуальних сполук в реакції з $\mathrm{ABTS}^{\bullet+}$. Його перевагою є можливість виключити вплив продуктів перетворення антиоксиданту на значення стехіометричного коефіцієнту інгібування $f_{A B T S+}^{r e d}$. Припускається що висока антирадикальна активність похідних $\mathrm{N}$-ариламінодигідроксифенілтіазолу обумовлена наявністю амідних груп, здатних виступати донорами електрону для відновлення катіон-радикалу $\mathrm{ABTS}^{*+}$.

\section{Подяка}

Автори висловлюють подяку співробітникам Інституту фізико-органічної хімії і вуглехімії ім. Л. М. Литвиненка НАН України Н. І. Буракову та О. Л. Каніболоцькому за синтез дигідроксифенілтіазолів.

Робота виконана за фінансової підтримки МOH України в рамках держбюджетних тем «Лакказо-медіаторні окиснювальні системи» (№ держреєстрації 0114U003515) і «Протонспряжений перенос електрона в гомолітичних реакціях фенолів у водних і водно-органічних середовищах» (№ держреєстрації 0117U002361).

\section{Перелік посилань}

1. Niki E. Assessment of antioxidant capacity in vitro and in vivo. Free Radical Biology and Medicine. 2010. Vol. 49. P.503-515.

2. Kinetics and mechanism of formation and decay of 2,2'-azinobis-(3-ethylbenzothiazole-6-sulphonate) radical cation in aqueous solution by inorganic peroxides / Venkatasubramanian L., Maruthamuthu P. Int. J. Chem. Kin. 1989. Vol.21. P. 399-421. 
3. Kinetic matching approach applied to ABTS assay for high-throughput determination of total antioxidant capacity of food products / Magalhaes L.M., Barreiros L., Reis S., Segundo M.A. Journal of Food Composition and Analysis. 2014. P.187-194.

4. Stopped-flow method for assessment of $\mathrm{pH}$ and timing effect on the ABTS total antioxidant capacity assay / Labrinea E.P., Georgiou C.A. Analytica Chimica Acta. 2004. Vol. 526. P. 63-68.

5. Synthesis and antiradical and antibacterial activity of 4-(3',4'-dihydroxyphenyl)thiazole derivatives / Odaryuk V.V., Burakov N.I., Kanibolotskaya L.V. et al. Pharmaceutical Chemistry Journal. 2015. Vol. 49, N 2. P. 96-98

6. Синтез и изучение антиоксидатной активности 3,4-дигидроксифенилтиазолов / Шендрик А.Н., Одарюк В.В., Бураков Н.И. и др. // Журнал органической и фармацевтической химии. 2011. Т.9, вип. 4 (36). С. 6164.

7. Ueber Verbindungen des Thiazols (Pyridins der Thiophenreihe) / Hantzsch A., Weber J. H. Dtsch. Chemischen Berichte. 1887. V. 20, N 2. P. 3118-3132.

8. Antioxidant activity applying an improved $\mathrm{ABTS}^{\bullet+}$ radical cation decolorization assay / Re R., Pellegrini N.,
Proteggente A. et al. Free Rad. Biol. Med. 1999. Vol. 26, N 9/10. P 231-1237.

9. Comparative reaction rates of various antioxidants with ABTS radical cation / Walker R.B., Everette J.D. J. Agric. Food Chem. 2009. Vol. 57, N 4. P. 1156-1161.

10. ABTS radical-driven oxidation of polyphenols: Isolation and structural elucidation of covalent adducts / Osman A. M., Wong K. K. Y., Fernyhough A. Biochemical and Biophysical Research Communications. 2006. Vol. 346, N 1. P. 321-329.

11. Индукционный период образования $\mathrm{ABTS}^{\cdot+}$ как характеристика антирадикальной активности ряда природных антиоксидантов / Ильясов И. Р., Белобородов В. Л., Тюкавкина Н. А. Фармацевтическая химия $и$ фармакогнозия. 2008. № 8. С. 14-18.

12. Антирадикальная способность фенольных антиоксидантов по отношению к катион-радикалу 2,2'азино-бис(3-этилбензтиазолин-6-сульфоновой кислоты) / Одарюк В.В., Одарюк И.Д., Каниболоцкая Л.В., Шендрик А.Н. Вестник Донеикого наџионального университета. Сер. Природничі науки. 2014. № 2. C. $121-125$.

Рукопис надійшов до редакиії 16.02.2017

\footnotetext{
УДК 547.(565+789.1)

Новый подход к определению антирадикальной способности фенолов в реакции с катион-радикалом 2,2'-азинобис(3-этилбензтиазолин-6-сульфоновой кислоты)

В. В. Одарюк, А. К. Сигаева, Л. В. Каниболоцкая, О. А. Зосенко, А. Н. Шендрик

Предложен подход к определению стехиометрического коэффициента ингибирования в реакции с катионрадикалом 2,2-азинобис(3-этилбензтиазолин-6-сульфоновой кислоты) $\left(\mathrm{ABTS}^{*+}\right)$, позволяющий исключить влияние продуктов превращения антиоксиданта на показатель антирадикальной способности. Высокая антирадикальная способность производных дигидроксифенилтиазола (ДФТ) в реакции с $\mathrm{ABTS}^{\cdot+}$ вызвана влиянием продуктов превращения ДФТ. Обсуждается механизм процесса.
}

Ключевые слова: антирадикальная способность, антиоксиданты, дигидроксибензолы, дигидроксифенилтиазолы, водная среда, ABTS.

A new approach for the determination of antiradical capacity of phenols in the reaction with cation-radical of 2,2'-azinobis(3-ethylbenzthiazoline-6-sulfonic acid)

V. V. Odariuk, H. K. Sigaeva, L. V. Kanibolotska, O. O. Zosenko, A. N. Shendrik

Vasyl' Stus Donetsk National University, Vinnytsya, Ukraine

It has been substantiated an approach to determining the stoichiometric coefficient of the inhibition in the reaction with the cation-radical 2,2'-azinobis(3-ethylbenzthiazoline-6-sulfonic acid) $\left(\mathrm{ABTS}^{-+}\right.$), which is allowed to exclude the effect of the antioxidant transformation products on the antiradical capacity. High antiradical capacity of dihydroxyphenylthiazole derivatives (DFT) in the reaction with $\mathrm{ABTS}^{\cdot+}$ is caused by the products of DFT transformation. The mechanism of the process is discussed. ABTS.

Keywords: antiradical capacity, antioxidants, dihydroxybenzenes, dihydroxyphenilthiazoles, aqueous medium,

References:

1. Niki, E. Assessment of antioxidant capacity in vitro and in vivo. Free Radical Biology and Medicine, 2010, 49 (4), 503-515 DOI: 10.1016/j.freeradbiomed.2010.04.016.

2. Venkatasubramanian, L.; Maruthamuthu, P. Kinetics and mechanism of formation and decay of 2,2'-azinobis-(3ethylbenzothiazole-6-sulphonate) radical cation in aqueous solution by inorganic peroxides. Int. J. Chem. Kin, 1989, 21, 399-421 DOI: 10.1002/kin.550210604.

3. Magalhaes, L. M.; Barreiros, L.; Reis, S.; Segundo, M. A. Kinetic matching approach applied to ABTS assay for high-throughput determination of total antioxidant capacity of food products. Journal of Food Composition and Analysis, 2014, 187-194 DOI: 10.1016/j.jfca.2014.01.003.

4. Labrinea, E. P.; Georgiou, C. A. Stopped-flow method for assessment of $\mathrm{pH}$ and timing effect on the ABTS total antioxidant capacity assay. Analytica Chimica Acta, 2004, 526 (1), 63-68 DOI: 10.1016/j.aca.2004.09.040. 
5. Odaryuk, V. V.; Burakov, N. I.; Kanibolotskaya, L. V. et al. Synthesis and antiradical and antibacterial activity of 4-(3',4'-dihydroxyphenyl)thiazole derivatives. Pharmaceutical Chemistry Journal, 2015, 49 (2), 96-98 DOI: $10.1007 / \mathrm{s} 11094-015-1229-5$.

6. Shendrik, A. N.; Odariuk, V. V.; Burakov, N. I. i dr. Sintez i izuchenie antioksidatnoi aktivnosti 3,4-digidroksifeniltiazolov [Synthez and antioxidant activity investigation of 3,4-dihydroxyphenylthiazoles]. Zhurnal organicheskoi $i$ farmatcevticheskoi khimii, 2011, 4, 61-64 (in Russian).

7. Hantzsch, A.; Weber, J. H. Ueber Verbindungen des Thiazols (Pyridins der Thiophenreihe). Dtsch. Chemischen Berichte, 1887, 20 (2), 3118-3132 DOI: 10.1002/cber.188702002200.

8. Re, R.; Pellegrini, N.; Proteggente, A. et al. Antioxidant activity applying an improved ABTS ${ }^{\bullet+}$ radical cation decolorization assay. Free Rad. Biol. Med, 1999, 26 (9/10), 1231-1237 DOI: 10.1016/S0891-5849(98)00315-3.

9. Walker, R.B.; Everette, J.D. Comparative reaction rates of various antioxidants with ABTS radical cation. J. Agric. Food Chem, 2009, 57 (4), 1156-1161 DOI: 10.1021/jf8026765.

10. Osman, A. M.; Wong, K. K. Y., Fernyhough, A. ABTS radical-driven oxidation of polyphenols: Isolation and structural elucidation of covalent adducts. Biochemical and Biophysical Research Communications, 2006, 346 (1), P. 321 329 DOI: 10.1016/j.bbrc.2006.05.118.

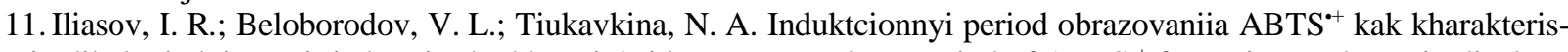
tika antiradikalnoi aktivnosti riada prirodnykh antioksidantov [Lag-phase period of $\mathrm{ABTS}^{\bullet+}$ formation as the antiradical activity characteristics of natural antioxidants] / Farmatcevticheskaia khimiia i farmakognoziia, 2008, 8, 14-18 (in Russian).

12. Odariuk, V. V.; Odariuk, I. D.; Kanibolotska, L. V.; Shendrik, A. N. Antyradykalna zdatnist fenolnykh antyoksydantiv po vidnoshenniu do kation-radykalu 2,2-azyno-bis(3-etylbenztiazolin-6-sulfonovoi kysloty) [Antiradical ability phenolic antioxidants in reaction with stable cation-radical 2,2'-azino-bis(3-ethylbenzthiazoline-6-sulfonic acid)]. Visnyk Donetskoho natsionalnoho universytetu. Seriia A: Pryrodnychi nauky, 2014, 18 (2), 121-125 (in Russian). 